\title{
Investigation of Long Term Mechanical Properties of Sulphur Polymer Concrete and Comparison with Portland Cement Concrete
}

\author{
Onur ÖZTÜRK ${ }^{1 *}$, Adnan ÖNER ${ }^{1}$ \\ ${ }^{1}$ Civil Engineering Department, Engineering Faculty, Kocaeli University, Kocaeli, 41001, TURKEY
}

Geliş / Received: 24/08/2020, Kabul / Accepted: 08/12/2020

\begin{abstract}
Sulphur polymer concretes (SPC) are widely used in construction technologies as building materials in recent years. Knowing the strength changes of SPCs used in structural members during their service life is of great importance in terms of building health. Therefore, it is aimed to determine the long-term strength changes of bitumen modified SPCs within the scope of this study. First, the sulphur modification was made using 2.5\% by weight of bitumen. Modified sulphur (MS) samples were examined with DSC and SEM to see if the modification was realized. Compressive, flexural and splitting tensile strength tests were carried out on SPC samples prepared with MS at the end of 1-hour, 1-day, 7, 28 and 360 days. Traditional Portland cement concrete (PCC) was prepared to be the same as the 28-day compressive strength of SPC, and the same tests were carried out to examine the results found comparatively. It was determined that the compressive, flexural and splitting tensile strength values of SPCs at the end of 1-hour reached $78 \%, 86 \%$ and $84 \%$, respectively. It was determined that while the long-term strength values of PCCs increased, the long-term strength of SPCs decreased.
\end{abstract}

Keywords: Sulphur polymer concrete, portland cement concrete, strength, mechanical properties

\section{Kükürt Polimer Betonların Uzun Dönemli Mekanik Özelliklerinin İncelenmesi ve Portland Çimento Betonları ile Karşılaştırılması}

\section{$\ddot{O} z$}

Kükürt polimer betonlar (SPC), son yıllarda yapı malzemesi olarak inşaat teknolojilerinde yaygın bir şekilde kullanılmaktadır. Yapısal elemanlarda kullanılan SPC'lerin servis ömürleri boyunca dayanım değişimlerinin bilinmesi yapı sağlığı açısından oldukça büyük önem taşımaktadır. Bu nedenle bu çalışma kapsamında bitüm kullanılarak modifiye edilen SPC'lerin uzun süreli dayanım değişimlerinin belirlenmesi amaçlanmıştır. İlk olarak ağırlıkça \% 2.5 oranında bitüm kullanılarak kükürt modifikasyonu yapılmıştır. Modifiye kükürt (MS) numuneleri DSC ve SEM ile incelenerek modifikasyonun gerçekleşip gerçekleşmediği incelenmiştir. MS ile hazırlanan SPC numuneleri üzerinde 1 saat ile 1, 7, 28 ve 360 gün sonunda basınç, eğilme ve yarma dayanımı deneyleri yapılmıştır. Bulunan sonuçların karşılaştırılmalı olarak incelenebilmesi için SPC'nin 28 günlük basınç dayanımları ile aynı olacak şekilde geleneksel Portland çimento beton (PCC) numuneleri hazırlanmış ve aynı deneyler gerçekleștirilmiștir. SPC'lerin 1 saat sonunda 28 günlük basınç, eğilme ve yarma dayanımı değerlerinin sırasıyla $\% 78, \% 86$ ve \%84'üne ulaştığı belirlenmiştir. PCC’lerin uzun süreli dayanım değerlerinde artış olduğu ancak SPC’lerin uzun süreli dayanımlarında azalmalar meydana geldiği belirlenmiştir.

Anahtar Kelimeler: Kükürt polimer beton, portland çimento betonu, dayanım, mekanik özellikler 


\section{Introduction}

Pure sulphur was first used as a building material in experimental studies conducted by Bacon and Davis in 1921. The aim of the research, which started in 1920 and continued until the end of the 1960s, was to show that sulphur could be used as an alternative in the construction industry (Kobbe, 1924; Duecker, 1934; Dale, 1966). Studies carried out after the beginning of the 1970s aimed to develop the strength and durability properties of construction materials obtained from sulphur. After the acceptance of the use of sulphur concretes as construction materials, high strength sulphur concrete was obtained by using basalt aggregate as a result of the study carried out by Crow et al. (1970) to improve the mechanical properties of concretes. However, in most of the experimental studies carried out until this date, pure sulphur was generally used as a binder in concrete. With the experimental studies carried out, it was determined that the concrete properties prepared using pure sulphur give excellent results. In contrast, their durability properties were evil, and that fragmentation and collapses occur in a short time (Yue et al., 2006). When pure sulphur and aggregate are prepared as a hot mixture and poured into the mould and left to cool, sulphur in the liquid form first takes the form of $S_{\beta}$ (monoclinic) crystal by showing $7 \%$ volume decrease at $114^{\circ} \mathrm{C}$. When the temperature goes below $95.4^{\circ} \mathrm{C}$ while cooling continues, $\mathrm{S}_{\beta}$ crystals turn into $S_{\alpha}$ (orthorhombic) crystals form. This form is also the crystal structure where sulphur is in the constant form at room temperature. These transition phases occur very quickly with cooling, and phase transitions are completed in less than 24 hours. Since the $S_{\alpha}$ crystal structure, which comes in a stable form at room temperature, is denser than the $S_{\beta}$ crystal structure, internal stresses occur in the sulphur binder and cause severe cracks to occur. Pure sulphur is modified under chemical or physical sulphur crystallization control to prevent this situation (Vlahovic et al., 2011). The additives used in the chemical control of sulphur crystallization can be summarized as dicyclopentadiene (DCPD) (Maraghechi et al., 2011; Shin et al., 2014) and combinations of DCPD, cyclopentadiene and dipentene (Bordoloi and Pierce, 1978; Lin et al., 1995). Sulphur crystallization can be physically prevented by using olefin hydrocarbon polymers and fly ash. The most commonly used olefin hydrocarbon polymers can be summarized as RP220, RP020, Escopol (Vroom, 1981) and bitumen (Mohamed and El Gamal, 2006, 2007, 2014; Al-Otaibi et al., 2018).

SPC is a thermoplastic material that uses modified sulphur (MS) as a binder and is prepared as a hot mixture with aggregate. SPCs are used as an alternative construction material to traditional Portland cement concretes (PCC) in many special engineering applications (Mohamed and El Gamal, 2006). SPC is also called "waterless concrete" because sulphur is used as a binder in concrete instead of cement+water used in traditional PCCs (Tautanji et al., 2010). SPCs are prominent to be used in construction applications to be carried out in space since water is not used in its content, sulphur is used as a binder, solidifies with cooling and sulphur is present as a free element on the moon surface (Grugel, 2012; Khoshnevis et al, 2016; Anyszka et al., 2016). At the same time, SPC has found its use in 3D printer technologies, taking into account its fast setting time and strength gain feature. (Hager et al., 2016). Experimental studies have also been carried out on the usability of SPCs as 
road pavement and concrete paving blocks due to their high abrasion resistance (AlOtaibi et al., 2018). There are also experimental studies in the literature to evaluate waste materials such as fly ash and recycled aggregate (Shin et al., 2014), electrolytic manganese residue (Yang et al., 2014), waste ilmenite mud (Contreras et al., 2013), cement kiln dust (Mohamed and El Gamal, 2011), crumb tire rubber particles (Maraghechi et al., 2011) in SPC.

The essential advantages of SPC over PCC are that setting time in less than 24 hours and high strength. (Contreras et al., 2013). In the study carried out by Vroom (1981), it was determined that SPC samples modified using olefin hydrocarbon polymer reached $80 \%$ of their ultimate strength at the end of 1-day and gained $100 \%$ at the end of 4-day. The changes in long-term strength values of SPCs were first examined by McBee et al. in the experimental study carried out in 1983. It was determined that the SPCs reached $70 \%$ of their ultimate strength a few hours after the start of cooling, and this ratio reached the range of $75-85 \%$ after 24-hour. Long-term strength values at the end of 180-day were examined, and it was seen that the samples reached their ultimate strength at the end of this period. The use of bitumen in sulphur modification was investigated in 2006 by Mohamed and El Gamal. In the experimental study (2007) performed on samples prepared with this proposed modification method, it was determined that the ultimate strength value reached $76 \%$ at the end of 1-day, and this rate was approximately $96 \%$ at the end of 3-day. It was observed that there was no significant change in 42-day long-term strength values. It is seen that there is a deficiency in the experimental studies examining the long-term strength changes of SPCs in the literature.
In this study, it is aimed to determine the long-term strength changes of SPCs prepared with bitumen modified sulphur. The changes in the compressive, flexural and splitting tensile strengths of SPC at the end of 1-hour, 1-day, 7, 28 and 360 days were determined and compared with PCC with the same 28day compressive strength values.

\section{Experimental Study}

\subsection{Materials}

In this study, pure sulphur released as a result of the Claus process was used in Tüpraşİzmit refinery. The purity of the sulphur supplied from the refinery was determined as $99.8 \%$. The physical and chemical properties of sulphur are given in Table 1 .

Table 1. Properties of sulphur

\begin{tabular}{ll}
\hline Properties & Result \\
\hline Appearance & $\begin{array}{l}\text { Solid particulate } \\
\text { (visual inspection) }\end{array}$ \\
\hline Odour & Odourless \\
\hline $\begin{array}{l}\text { Melting/freezing } \\
\text { point }\left({ }^{\circ} \mathrm{C}\right)\end{array}$ & 119 (ASTM D-97) \\
\hline $\begin{array}{l}\text { Boiling point starting } \\
\left({ }^{\circ} \mathrm{C}\right)\end{array}$ & 445 (ASTM D-86) \\
\hline $\begin{array}{l}\text { Relative density } \\
\left(15^{\circ} \mathrm{C}\right)(\mathrm{kg} / \mathrm{L})\end{array}$ & 2.1 (ASTM D1298) \\
\hline $\begin{array}{l}\text { Flaming point } \\
\text { temperature }\left({ }^{\circ} \mathrm{C}\right)\end{array}$ & $206($ ASTM D-93) \\
\hline
\end{tabular}

Bitumen (50/70 penetrated) with the viscosity of $416 \mathrm{cSt}$ at $135^{\circ} \mathrm{C}$, softening point of $49^{\circ} \mathrm{C}$, specific gravity $1.034 \mathrm{of} \mathrm{g} / \mathrm{cm}^{3}$ and with a chemical analysis of $79 \%$ carbon, $10 \%$ hydrogen, $3.3 \%$ sulphur, $0.7 \%$ nitrogen was used as a chemical additive for sulphur modification. In this study, CEM I 42.5 type Portland cement was used as a binder in PCC, and F class fly ash supplied from Çatalağzı Thermal Power plant was used as filler in SPC. The specific gravity of cement and fly ash were $3.14,2.29 \mathrm{~g} / \mathrm{cm}^{3}$, and the 
specific surface areas were 3420 and 2765 $\mathrm{cm}^{2} / \mathrm{g}$, respectively. Chemical properties of

cement and fly ash are given in Table 2 .

Table 2. Chemical properties of cement and fly ash

\begin{tabular}{|c|c|c|c|c|c|c|c|c|c|c|c|}
\hline & \multicolumn{9}{|c|}{ Chemical compositions (\%) } & \multirow{2}{*}{ LOI* } & \multirow{2}{*}{$\mathrm{IM}^{* *}$} \\
\hline & $\mathrm{SiO}_{2}$ & $\mathrm{Al}_{2} \mathrm{O}_{3}$ & $\mathrm{Fe}_{2} \mathrm{O}_{3}$ & $\mathrm{CaO}$ & $\mathrm{MgO}$ & $\mathrm{SO}_{3}$ & $\mathrm{Na}_{2} \mathrm{O}$ & $\mathrm{K}_{2} \mathrm{O}$ & $\mathrm{Cl}^{-}$ & & \\
\hline Cement & 22.10 & 4.37 & 3.30 & 65.63 & 1.20 & 2.62 & 0.28 & 0.46 & 0.048 & 2.64 & 0.68 \\
\hline Fly Ash & 57.32 & 25.21 & 6.86 & 1.47 & 1.86 & 0.47 & 0.41 & 4.08 & 0.01 & 1.19 & - \\
\hline
\end{tabular}

* LOI: Loss on ignition

* IM: Insoluble material

The same aggregates were used in the castings of SPC and PCC; natural sand is used as fine aggregate and crushed stone as coarse aggregate. The fineness module of natural sand was 2.28, and its specific weight was $2.60 \mathrm{~g} / \mathrm{cm}^{3}$, the fineness module of crushed stone was 4.88 , and its specific weight was $2.68 \mathrm{~g} / \mathrm{cm}^{3}$. Polycarboxylate based superplasticizer was used in PCC. The plasticizer with a density of $1.08 \mathrm{~g} / \mathrm{cm}^{3}$ was used in the mixtures at a rate of $1.3 \%$ of the cement weight.

\subsection{Preparation of Specimens}

Bitumen was used to modify pure sulphur in this study. For sulphur modification, pure sulphur, which is available in granular form, was placed in a temperature-controlled mechanical mixer (Fig. 1) heated between $130-135^{\circ} \mathrm{C}$ and mixed until it reaches the liquid phase. Then, $2.5 \%$ by weight of bitumen was added to the liquid sulphur. The asphalt emulsifier was added to the mixture at a specified rate $(0.025 \mathrm{~g} / 100 \mathrm{~g})$ so that the bitumen can spread homogeneously in liquid sulphur and that sulphur-bitumen reactions can take place literally. The mixture was mixed with the mechanical mixer for 60 minutes to form a reaction between the sulphur, bitumen and asphalt emulsifier in the liquid phase. The temperature was kept constant between $130-135^{\circ} \mathrm{C}$ during the mixing process. After the mixing process was completed, the MS was allowed to cool to 7$13^{\circ} \mathrm{C}$ per minute at room temperature.

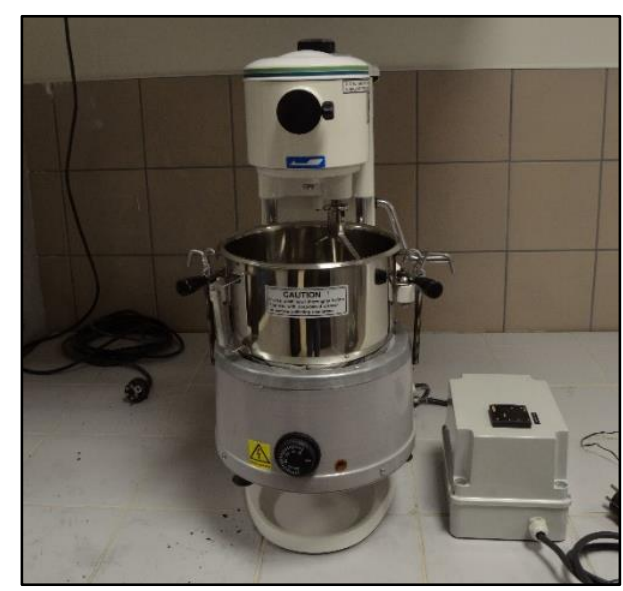

Figure 1. Temperature-controlled mechanical mixer

In the preparation of SPC, pure sulphur, MS, fly ash, natural sand and crushed stone weight ratios were used as $33.95 \%, 1.05 \%$, $35 \%, 15 \%$ and $15 \%$, respectively. All equipment used in mixing concrete, filling the moulds and smoothing the surface was used after heating in the oven between 130$135^{\circ} \mathrm{C}$ for 2 hours, as shown in Fig. 2. 


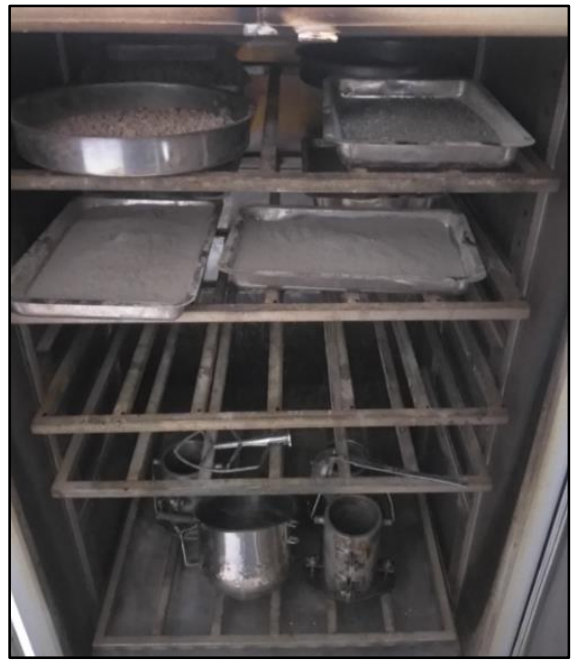

Figure 2. Materials and equipment kept in the oven

After fixing the temperature-controlled mechanical mixer between $130-135^{\circ} \mathrm{C}$, pure sulphur was allowed to come into the liquid phase by being mechanically mixed. After the pure sulphur melted and liquefied, the fly ash, which was kept in the oven, was added and mixed for a total of 20 minutes, at a low speed for 10 minutes and high speed for 10 minutes, to make the mixture homogeneous. Then, the determined ratio of MS was added, and mixing was continued for 10 minutes. Natural sand and crushed stone, which was heated in the oven, was added to the mixture consisting of pure sulphur, MS and fly ash, and it was allowed to mix for a minimum of 20 minutes until it was sure that the mixture becomes homogeneous. The concrete mixture was filled into a $75 \times 75 \times 254 \mathrm{~mm}$ prism and 100x200 mm cylinder metal moulds heated in the oven. Placement of the SPC mixture, which was placed in metal moulds with the help of a plastic mallet and a hot iron bar, was completed. All samples were allowed to cool at room temperature.

Within the scope of this study, after the castings of SPC, 28-day compressive strengths were determined. The determined compressive strength value was chosen as the target strength of the PCC to make comparisons with the same compressive strength properties. Many trial castings were carried out, and the required mixing ratios were determined to provide this strength value. Cement dosage was taken as $400 \mathrm{~kg}$, and the water/cement ratio was 0.50 in PCC. The same aggregate was used with SPC, and the amount of natural sand and crushed stone were determined as 673.7 and $1041.7 \mathrm{~kg} / \mathrm{m}^{3}$, respectively. The chemical additive was used as $1.3 \%$ of cement weight. The weight ratios of the materials used in SPC and PCC are summarized graphically in Fig. 3.

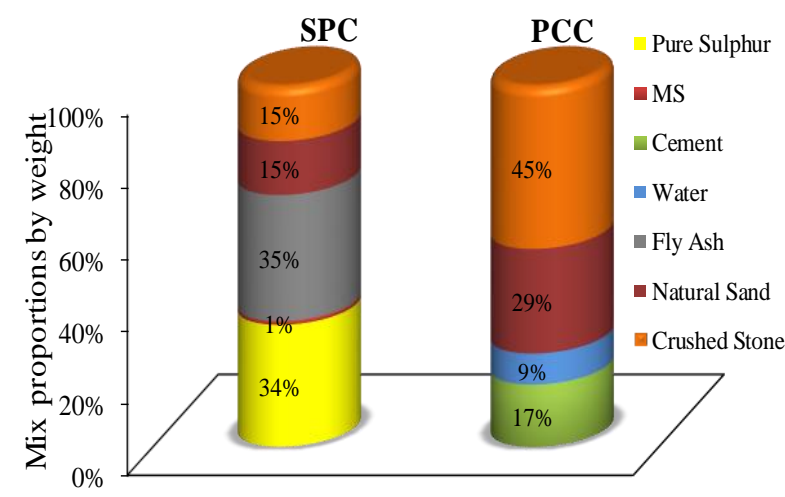

Figure 3. Mix proportions of SPC and PCC

\section{Experimental Results}

\subsection{Sulphur modification}

DSC and SEM analyses were performed on both pure sulphur and MS samples to determine whether the sulphur modification was performed. DSC samples were prepared as $10 \mathrm{mg}$ in an aluminium pan. All samples were first heated from room temperature to $150^{\circ} \mathrm{C}$ (first temperature loading) and then cooled to room temperature (second temperature loading). In the last temperature loading, samples that reached room temperature were heated to $150^{\circ} \mathrm{C}$ again (third temperature loading). In all temperature loadings, the temperature increment was adjusted to be $5^{\circ} \mathrm{C} / \mathrm{min}$. DSC 
diagrams obtained from pure sulphur and MS samples are given in Fig. 4.

In the first temperature loading applied to pure sulphur, firstly $S_{\alpha}$ and then $S_{\beta}$ crystals melted at $104.97^{\circ} \mathrm{C}$ and $120.68^{\circ} \mathrm{C}$. When the applied temperature reached $150^{\circ} \mathrm{C}$, cooling was started to room temperature as the second temperature loading. During the cooling process, $\mathrm{S}_{\alpha}$ crystallization was observed at $56.41{ }^{\circ} \mathrm{C}$ in liquid sulphur. It was determined that the $\mathrm{S}_{\alpha}$ crystals formed in the third temperature loading melted at $106.93^{\circ} \mathrm{C} . \mathrm{S}_{\alpha}$ and then $\mathrm{S}_{\beta}$ crystals melted at $104.85^{\circ} \mathrm{C}$ and $120.32^{\circ} \mathrm{C}$ at the first temperature loading at $\mathrm{MS}$ sample. Unlike pure sulphur sample, it was observed that $S_{\beta}$ crystallization occurred at $31.71^{\circ} \mathrm{C}$ in $\mathrm{MS}$ sample during cooling (second temperature loading). In the third temperature loading, it was determined that the $S_{\beta}$ crystals melted at $117.46^{\circ} \mathrm{C}$.
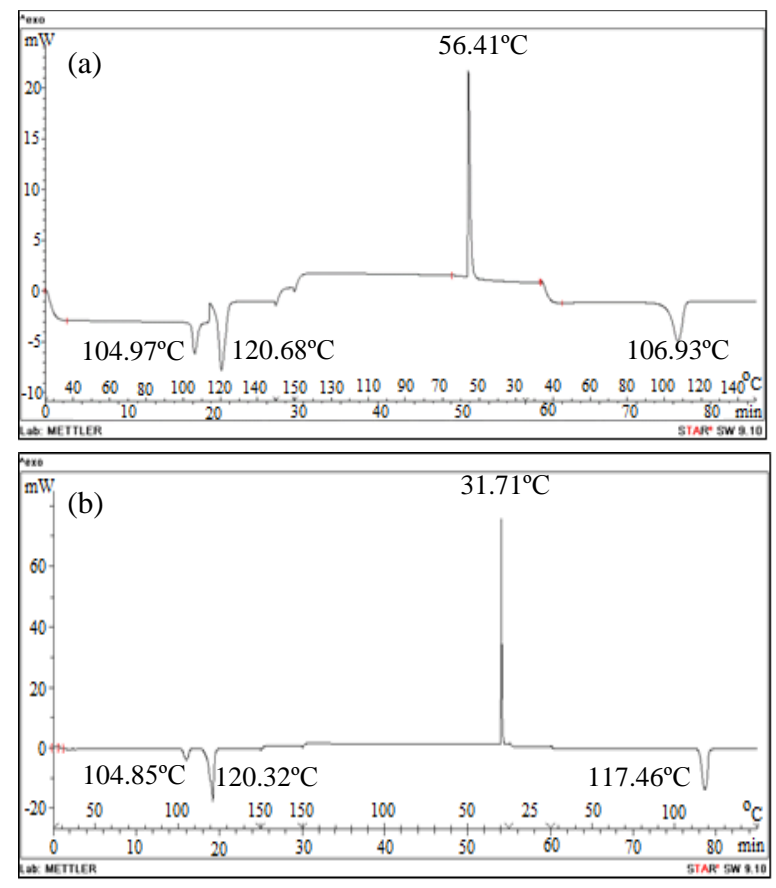

Figure 4. DSC diagram of (a) pure sulphur and (b) MS

SEM images obtained from pure sulphur and MS samples are given in Fig. 5. Pure sulphur was found to have a large and dense $\mathrm{S} \alpha$ crystalline structure with orthorhombic sulphur morphology after crystallization. Also known as rhombic sulphur, orthorhombic sulphur is the structure where sulphur is stable at room temperature and under atmospheric pressure. With the addition of $2.5 \%$ by weight of bitumen into pure sulphur, crystal growth was limited by bitumen and controlled. The conversion of sulphur, which turned into a monoclinic phase with a plate-like appearance, to the orthorhombic phase was prevented.

It was determined that the dense and wide orthorhombic crystal structure belonging to pure sulphur remained stable in monoclinic crystal form, and $\mathrm{S}_{\beta}-\mathrm{S}_{\alpha}$ conversion did not occur as a result of adding $2.5 \%$ bitumen in pure sulphur. Modification of pure sulphur appears to be successful with the addition of bitumen.

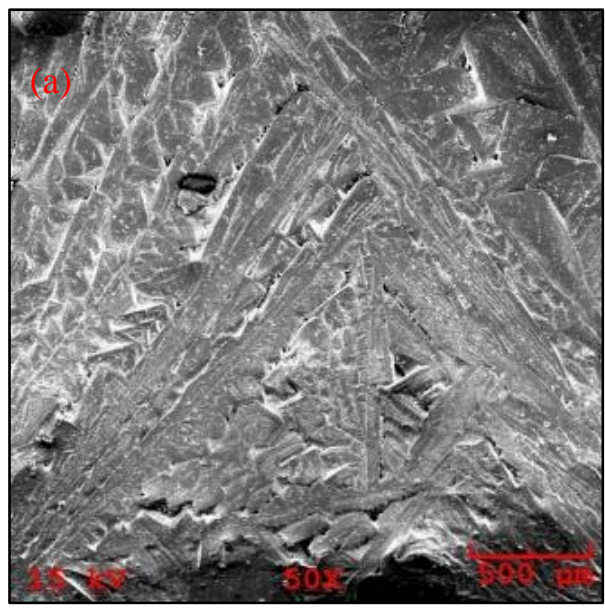




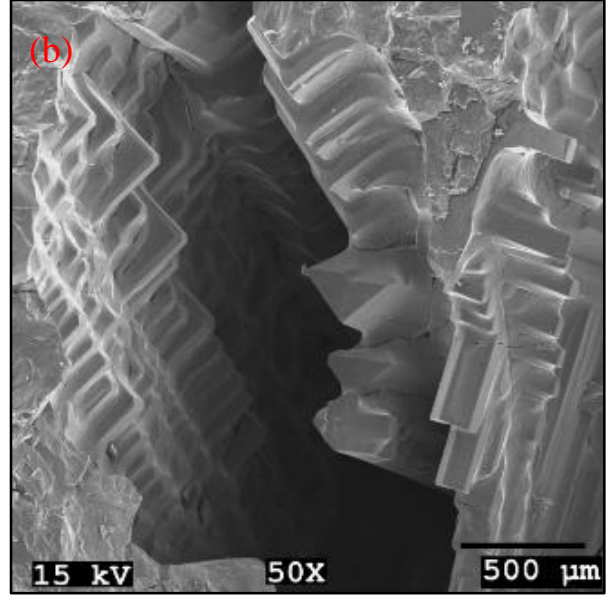

Figure 5. SEM images of (a) pure sulphur and (b) MS

\subsection{Mechanical properties}

In this study, compressive strength, flexural strength and splitting tensile strength tests were carried out to determine the mechanical properties of SPC and PCC. A total of 35 SPC and 21 PCC 100x200 mm cylindrical samples were prepared to determine the compressive and splitting tensile strength. The prepared SPC and PCC cylinder samples are shown in Fig. 6. A total of 15 SPC and 9 PCC $75 \times 75 \times 254 \mathrm{~mm}$ prism samples were prepared to determine bending strengths.

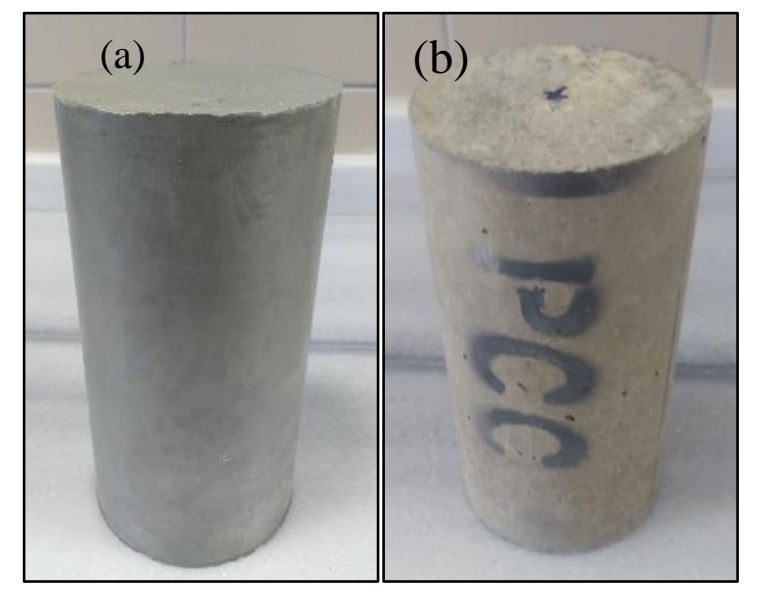

Figure 6. (a) SPC and (b) PCC cylinder

Experiments of mechanical properties were performed at the 7,28 and 360 days of concretes. While strength tests of 1-hour and 24-hour were carried out in SPC, since the PCC could not be removed from the mould, strength tests could not be performed. The SPC sample obtained after 1 hour is shown in Fig. 7. Compressive, flexural and splitting tensile strength tests were carried out in accordance with ASTM C-39, ASTM C-293 and ASTM C-496 standards, respectively.

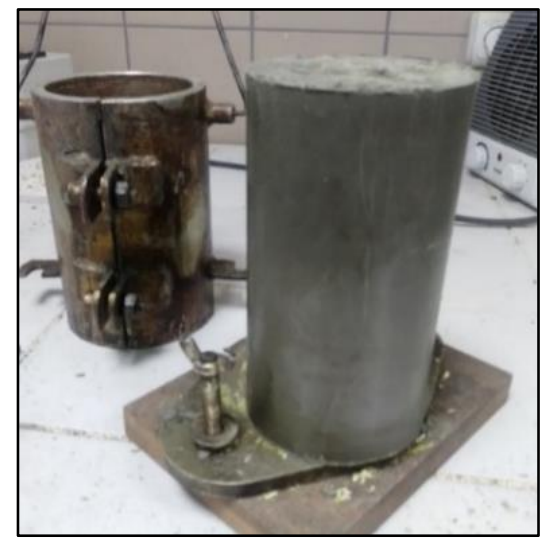

Figure 7. Cylinder SPC sample after one hour

All results and averages obtained from compressive, flexural and splitting tensile strength tests are shown in Table 3.

Table 3. Mechanical properties of SPC and PCC

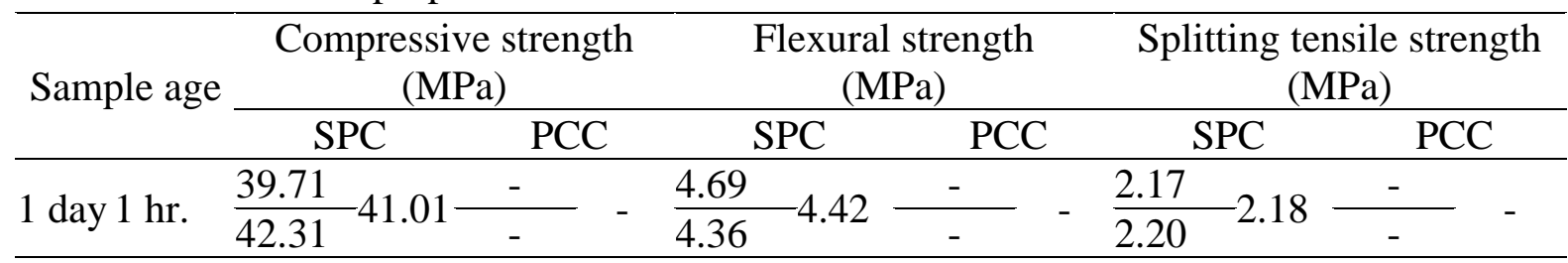




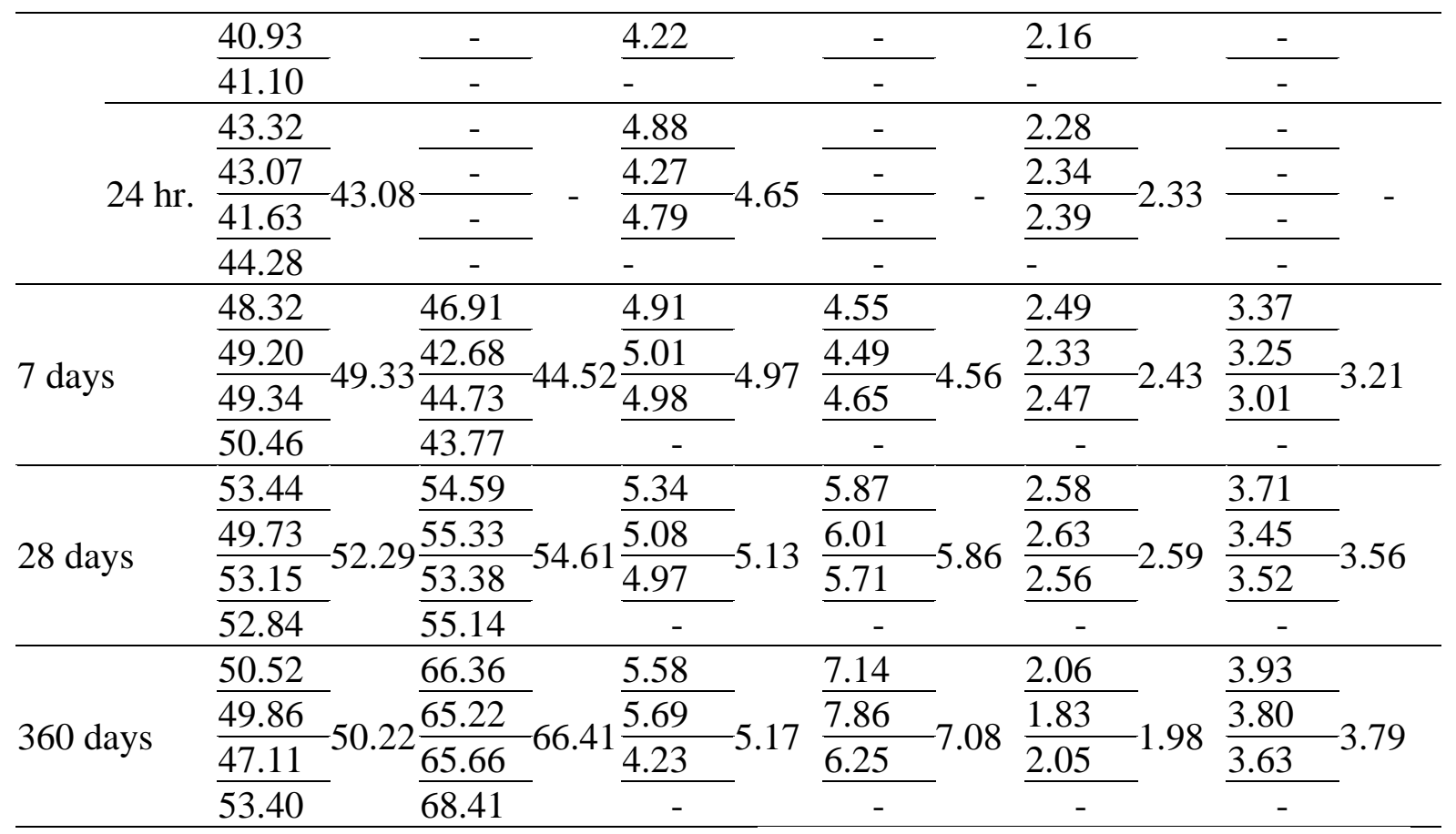

The average compressive, flexural, splitting tensile strength and age relationship graph obtained from SPC and PCC samples is given in Fig. 8-10, respectively.
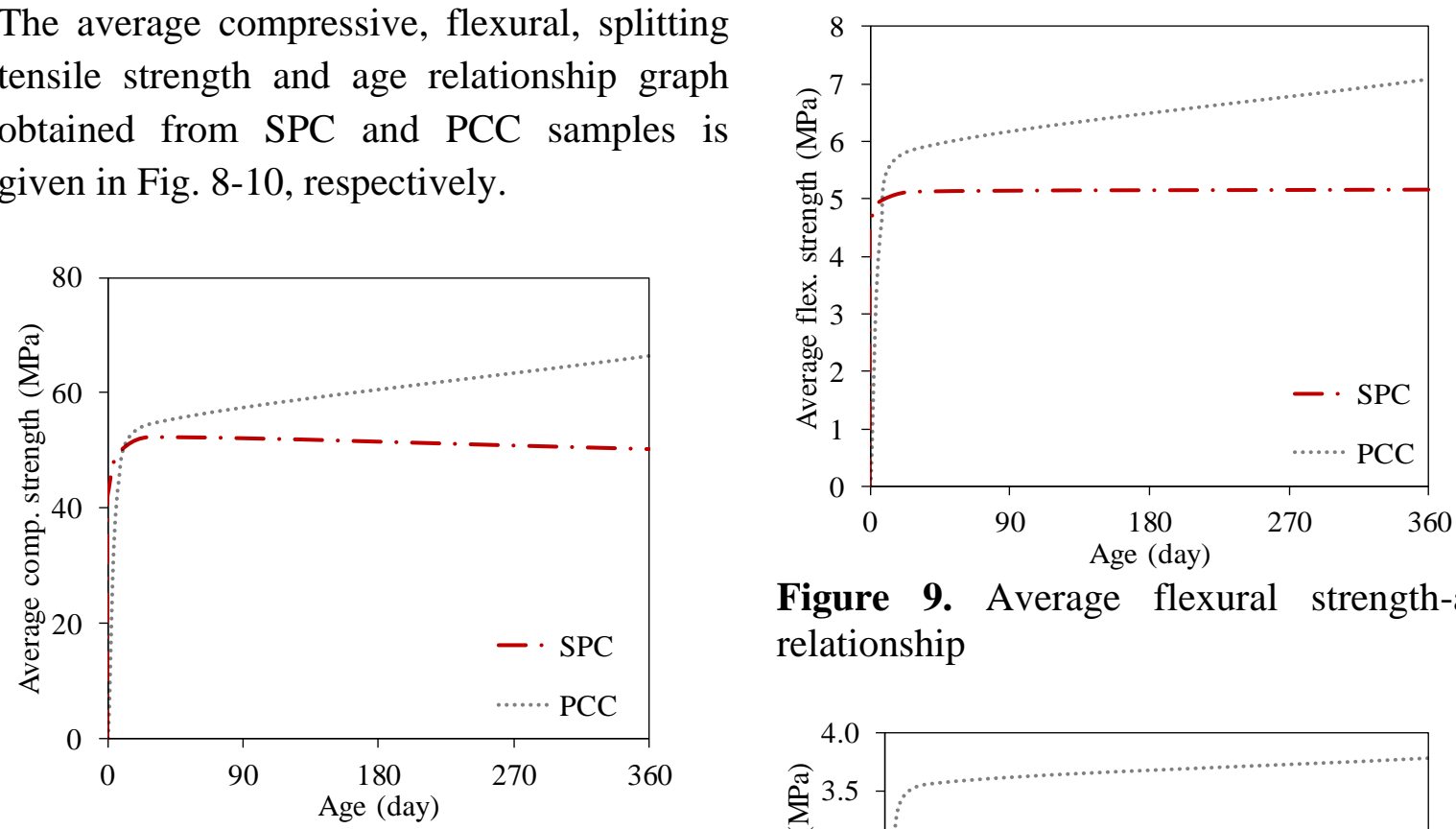

Figure 9. Average flexural strength-age relationship

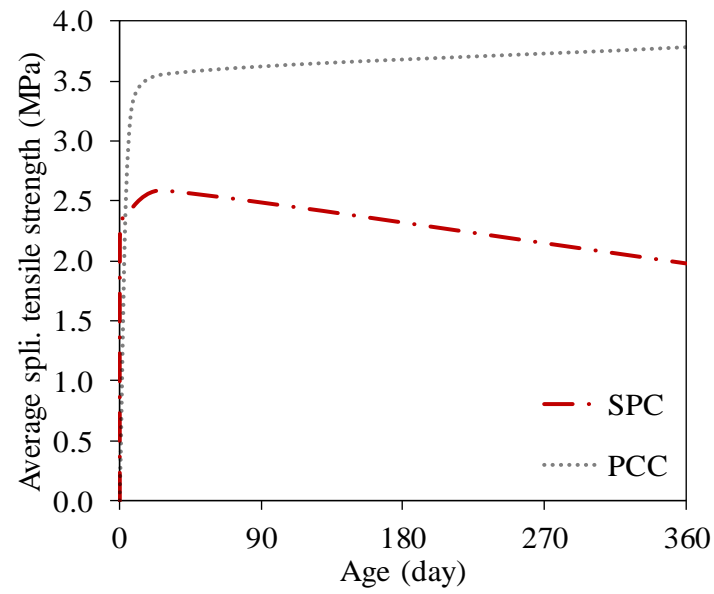

Figure 10. Average splitting tensile strengthage relationship 
The 28-day average compressive, flexural and splitting tensile strength values were found to be 52.19, 5.13 and $2.59 \mathrm{MPa}$ in SPC, respectively; while these values were found as 54.61, 5.86 and $3.56 \mathrm{MPa}$, respectively, in PCC. The strength values of SPC at the end of 1-hour were determined as $78 \%, 86 \%$ and $84 \%$ for the compressive, flexural and splitting tensile strengths of the 28-day strength values, respectively. The compressive strength test results made by McBee et al. (1983) showed that the SPC reached approximately $70 \%$ of the ultimate strength after 1 hour. It has been observed that the 1-hour compressive strength ratio obtained from this experimental study is compatible with the existing studies in the literature. It was determined that the compressive strength value of SPC at the end of 1-day is $82 \%$ of the 28-day compressive strength value. This rate found to be $80 \%$ (Vroom, 1981), 75-85\% (McBee et al., 1983) and $76 \%$ (Mohamed \& El Gamal, 2007) in the existing studies from the literature, and this is in line with the results of the experimental research. Strengths at the 7-day of concretes compared with the 28-day strengths were reached $82 \%$ in PCC and 94\% in SPC for compressive strength, $78 \%$ in PCC and 97\% in SPC for flexural strength, 90\% in PCC and 94\% in SPC for splitting tensile strength. It can be seen from the graphs that the strength values of SPC that reach after 1-hour, the PCC can reach after approximately 7-day.

The changes of the strength values of SPC at the end of 360-day according to the 28-day strength values were found to be $14 \%$ decrease, $1 \%$ increase and $31 \%$ decrease, respectively, for compressive, flexural and splitting tensile strengths. The strength values of PCC at the end of 360 days were increased compared to the 28-day strength values. The increasing rates were found to be $18 \%, 17 \%$ and $6 \%$ for compressive, bending and splitting strengths, respectively. It was seen that there was an increase in the longterm strength changes of PCCs, unlike SPCs.

\section{Conclusions}

The results obtained from the experimental study conducted to determine the long-term mechanical properties of SPC and compare with PCC are summarized below.

The strength values of SPC at the end of 1hour reached $78 \%, 86 \%$ and $84 \%$ of the 28 day strength values for compression, bending and splitting tensile strength, respectively.

The 1-hour strength value of SPC was determined to be close to the 7-day strength values of PCC.

It is seen that the use of SPC is more suitable than PCC in specific engineering applications that require early strength and mould removal.

While the long-term strength values of PCC are increasing, it has been determined that SPC has the long-term strength losses of up to $31 \%$.

It is seen that it is essential to make design considering the strength losses that may occur in the long-term in SPC applications.

\section{References}

Al-Otaibi, S., Al-Aibani, A., Al-Bahar, S., Abdulsalam, M., Al-Fadala S. 2018. "Potential for Producing Concrete Blocks Using Sulphur Polymeric Concrete in Kuwait", JKSUES, 31(4), 327-331.

Anyszka, R., Bielinski, D.M., Sicinski, M., Imiela, M., Szajerski, P., Pawlica, J., Walendziak, R. 2016. "Sulfur ConcretePromising Material for Space-Structures 
Building", European Conference on Components as the Future of Sustainable Spacecraft Structures Materials and Construction", Procedia Engineering, 151, Environmental, Toulouse, France. 292-299.

ASTM C-39. 2018. "Standard Test Method for Compressive Strength of Cylindrical Concrete Specimens", American Society for Testing and Materials, Pennsylvania.

ASTM C-293. 2016. "Standard Test Method for Flexural Strength of Concrete (Using Simple Beam with Center-Point Loading)", American Society for Testing and Materials, Pennsylvania.

ASTM C-496. 2017. "Standard Test Method for Splitting Tensile Strength of Cylindrical Concrete Specimens", American Society for Testing and Materials, Pennsylvania.

Bacon, R.F., Davis, H.S. 1921. "Recent Advances in the American Sulfur Industry", Chemical and Metallurgical Engineering, 24, 65-72.

Bordoloi, B.K., Pierce, E.M. 1978. "Plastic Sulfur Stabilization by Copolymerization of Sulfur with Dicyclopentadiene", Adv. Chem., 31-53.

Contreras, M., Gazquez, M.J., Garcia-Diaz, I., Alguacil,, F.J., Lopez F.A., Bolivar, J.P. 2013. "Valorization of Waste Ilmenite Mud in the Manufacture of Sulphur Polymer Cement", J. Environ. Manage, 128, 625-630.

Crow, L.J., Bates, R.C. (1970). "Strength of Sulfur-Basalt Concretes", U.S. Bureau of Mines, Report No: RI 7349, 21.

Dale, J.M., Ludwig, A.C. (1966). “Advanced Studies of Sulfur Aggregate Mixtures as a Structural Material", Southwest Research Institute, Report No: AFWL-TR-68-21.

Duecker, W.W. 1934. “Admixtures Improve Properties of Sulfur Cements", Chemical Metallurgical Engineering, 41(11), 583-586.

Grugel, R.N. 2012. "Integrity of Sulfur Concrete Subjected to Simulated Lunar Temperature Cycles", Adv. Space Res., 50, 1294-1299.

Hager, I., Golonka,, A., Putanowicz R. 2016. "3D Printing of Buildings and Building

Khoshnevis, B., Yuan, X., Zahiri, B., Zhang, J., Xia, B. 2016. "Construction by Contour Crafting Using Sulfur Concrete with Planetary Applications", Rapid Prototyp. J., 22(5), 848-856.

Kobbe, W.H. 1924. "New Uses for Sulfur in Industry", Industrial \& Engineering Chemistry, 16(10), 26-1028.

Lin, S.L., Lai, J.S., Chian, E.S.K. 1995. "Modification of sulfur polymer cement (spc) stabilization and solidification $(\mathrm{s} / \mathrm{s})$ process", J. Waste Manag., 15, 441-447.

Maraghechi, H., Ahmadi, I.F., Motahari, S. 2011. "Effect of Adding Crumb Tire Rubber Particles on the Mechanical Properties of DCPD-Modified Sulfur Polymer Mortars", $J$ Mech Mater Struct, 6(9-10), 1283-1294.

McBee, W.C., Sullivan, T.A., Jong, B.W. (1983). "Corrosion Resistant Sulfur Concretes", U.S. Bureau of Mines, Report No: $8758,28$.

Mohamed, A.M.O., El Gamal, M.M. 2006. "Compositional Control on Sulfur Polymer Concrete Production for Public Works", Development in Arid Regions Research, 3, 27-38.

Mohamed, A.M.O., El Gamal M.M. 2007. "Sulfur Based Hazardous Waste Solidification", Environ. Geol, 53(1), 159175.

Mohamed, A.M.O., El Gamal, M.M. 2011. "Solidification of Cement Kiln Dust Using Sulfur Binder", J. Hazard. Mater, 192, 576584.

Mohamed, A.M.O., El-Dieb, A., El Sawy, K.M., El Gamal, M.M. 2014. "Durability of Modified Sulphur Concrete in Sewerage Environment", Environ Geotech, 2(2), 1-9.

Shin, M., Kim, K., Gwon,, S.W., Cha S. 2014. "Durability of Sustainable Sulfur Concrete with Fly Ash and Recycled Aggregate Against Chemical and Weathering 
Environments", Constr Build Mater, 69, 167176.

Tautanji, H.A., Evans, S., Grugel, R.N. 2010. "Performance of -Waterless Concrete-", CPIC 2010-13th International Congress on Polymers in Concrete, Funchal-Maderia, Portugal.

Vlahovic, M.M., Martinovic, S.P., Boljanac, T.D., Jovanic, P.B., Volkov-Husovic, T.D. 2011. "Durability of Sulfur Concrete in Various Aggressive Environments", Constr Build Mater, 25, 3926-3934.

Vroom, A.H. (1981). "Sulfur cements, process for making same and sulfur concretes made there from", U.S. Patent No. 4,293,463.

Yang, C., Lv, X., Tian, X., Wang, Y., Komarneni, S. 2014. "An Investigation on the Use of Electrolytic Manganese Residue as Filler in Sulfur Concrete", Constr Build Mater, 73, 305-310.

Yue, L., Caiyun,, J., Yunping X. 2006. "The Properties of Sulfur Rubber Concrete (SRC)", J. Wuham Univ. Technol. Mater. Sci., 21(1), 129-133. 